\title{
Spatial and temporal dynamics of the abundance of crustose calcareous algae on the southernmost coral reefs of the western Atlantic (Abrolhos Bank, Brazil)
}

\author{
Gilberto M. Amado-Filho ${ }^{1, *}$, Ricardo G. Bahia ${ }^{1}$, Rodrigo Mariath ${ }^{1}$, Michel B. Jesionek ${ }^{1}$, \\ Rodrigo Leão Moura ${ }^{2}$, Alex C. Bastos ${ }^{3}$, Guilherme Henrique Pereira-Filho ${ }^{4}$ and Ronaldo \\ Bastos Francini-Filho ${ }^{5}$ \\ ${ }^{1}$ Instituto de Pesquisas Jardim Botânico do Rio de Janeiro, Diretoria de Pesquisa Científica, Rua Pacheco Leão 915, Rio de \\ Janeiro, RJ 22460-030, Brazil \\ ${ }^{2}$ Instituto de Biologia, Universidade Federal do Rio de Janeiro, Rio de Janeiro, RJ 21941-599, Brazil \\ ${ }^{3}$ Departamento de Oceanografia, Universidade Federal do Espírito Santo, Avenida Fernando Ferrari 514, Vitória, \\ ES 29090-600, Brazil \\ ${ }^{4}$ Instituto do Mar, Universidade Federal de São Paulo, Campus Baixada Santista, Santos, SP 11030-400, Brazil \\ ${ }^{5}$ Centro de Ciências Aplicadas e Educação, Universidade Federal da Paraíba, Campus IV-Litoral Norte, Rio Tinto, \\ PB 58297000, Brazil
}

Crustose calcareous algae (CCA) constitute one of the main reef builders on the Abrolhos Bank, Brazil. Once CCA taxonomy is locally understood, differences in growth-forms may be useful for the delimitation of taxa using characteristics such as the presence or absence of surface protuberances. Here, growth-forms were used to identify and quantify the most common CCA taxa on the shallow reefs (3-10 m) of the Abrolhos Bank to determine possible changes in the CCA community over a period of 10 years, and the ecological significance of CCA to local reefs was interpreted. The CCA assemblages were surveyed from 2006-2015 by using fixed photoquadrats at four sites in the inner (10-20 km from the mainland) and mid-shelf reefs (40-75 km from the mainland). The five most common CCA taxa were Pneophyllum conicum, the Lithophyllum kaiserii / Lithophyllum sp. complex, Melyvonnea erubescens, the Hydrolithon boergesenii / Porolithon onkodes complex and Peyssonelia sp. The overall mean CCA cover on the reefs was $20 \%$. A comparison with a previous monitoring study in the same region indicated that the CCA cover nearly doubled from 2003-2008 to 2006-2015. This study reveals that the coral-killing species P. conicum dominated CCA flora on the shallow Abrolhos reefs in the last decade, and the local specific abundance of CCA slightly fluctuated over time and was species- and site-specific. The information obtained in this study contributes to the understanding of the ecology of the key calcifying components of the Abrolhos reefs and provides a useful baseline for exploring the responses of CCA to future environmental changes.

Key Words: Brazil; coral reef; ecology; macroalgae; reef community; South Atlantic terms of the Creative Commons Attribution Non-Commercial License (http://creativecommons.org/licenses/by-nc/3.0/) which permits unrestricted non-commercial use, distribution, and reproduction in any medium, provided the original work is properly cited.
Received September 1, 2017, Accepted February 25, 2018

*Corresponding Author

E-mail: gilbertoamadofilho@gmail.com Tel: +55-21-32042150 


\section{INTRODUCTION}

The Abrolhos Bank, off the coast of Brazil, harbours the largest and richest coral reefs in the South Atlantic. Because of the importance of live crustose calcareous algae (CCA) (here referring to Corallinales, Hapalidiales, Sporolithales, and Peyssonneliales) as major frame-builders, Abrolhos reefs are significantly different from other well-studied reefs (e.g., Caribbean and Indo-Pacific) where corals are the principal reef-builders (Leão and Domingues 2000, Leão et al. 2003, Amado-Filho et al. 2012, Francini-Filho et al. 2013, Moura et al. 2013, Reis et al. 2016). In addition to being framework builders, CCA are early colonizers of available marine hard substrata (Foster 1975, Quinn 1982, Steneck 1986, Kendrick 1991, Mariath et al. 2013) and play important roles in the cementation and accretion of tropical reefs (Adey 1975, Johansen 1981). They are also important substrata for scleractinian coral settlement and early growth (Babcock and Mundy 1996, Harrington et al. 2004).

Reef health has been evaluated by a range of indices and single indicators (Díaz-Pérez et al. 2016). Among them, the proportions in abundance of reef-builders (e.g., corals and CCA) vs. non-reef-builders (e.g., fleshy macroalgae) and the rates of accretion vs. erosion in the reef ecosystem have been widely used as metrics for reef health (Silbiger et al. 2014, Reis et al. 2016). Reefs dominated by reef-builders with rates of accretion higher than those of erosion are usually considered as healthy ones (Reis et al. 2016). On the other hand, if dominant species are non-reef-builders and erosion rates are higher than accretion rates, it can be a signal of an unhealthy reef (Perry et al. 2008, Sweatman et al. 2011), although there are exceptions (Vroom et al. 2006).

In contrast with fleshy macroalgae, the invasion of CCA and deleterious effects on corals are considered uncommon (Benzoni et al. 2011, Eckrich et al. 2011). However, at least seven CCA species have been reported to overgrow and kill living corals: Harveylithon rupestre (Foslie) A. Rösler, Perfectti, V. Peña \& J. C. Braga (as Hydrolithon rupestre), Hydrolithon murakoshii Iryu \& Matsuda, Lithothamnion sp., Pneophyllum conicum (E. Y. Dawson) Keats, Porolithon onkodes (Heydrich) Foslie, Metapeyssonnelia milleporoides D. L. Ballantine \& H. Ruiz, and Ramicrusta textilis Pueschel \& G. W. Saunders (Keats et al. 1997, Antonius 2001, Pueschel and Saunders 2009, Ballantine and Ruiz 2011, Benzoni et al. 2011). Among them, P. conicum has been identified in the Indo-Pacific as one of the most aggressive scleractinian coral killers, representing a syndrome of epizoism (Keats et al. 1997,
Antonius 2001). This species was recently reported on south Atlantic coralgal reefs (Mariath et al. 2012), including those from the Abrolhos Bank (Jesionek et al. 2016), leading to concerns on the need for its monitoring and understanding of possible environmental impacts.

CCA are widely distributed around the world from the poles to the tropics and from intertidal areas to depths close to $300 \mathrm{~m}$ (Steneck 1986, Nelson 2009). Differences in their growth-forms have been widely used to visually delimit and identify genera, species and infraspecific taxa for over 200 years (Woelkerling et al. 1993). However, most modern (since 1980) taxonomic studies on CCA have considered that the external morphological features are too variable to be used as taxonomic characteristics, giving priority, rather, to internal vegetative and reproductive anatomical features for taxonomy (e.g., Woelkerling 1988, Penrose 1992, Verheij 1993). Some CCA species (according to anatomical criteria) can have wide growthform plasticity, whereas different species can display similar external morphologies (Riosmena-Rodríguez et al. 1999, Harvey et al. 2005), as these features can be controlled by environmental conditions (Steneck and Adey 1976).

Most recently, the incorporation of molecular data in CCA taxonomic studies revealed the existence of cryptic speciation where genetically different species have similar morpho-anatomical features (e.g., Broom et al. 2008, Bittner et al. 2011, Carro et al. 2014, Sissini et al. 2014, Hernandez-Kantun et al. 2016). In other cases, anatomically similar specimens with distinct growth-forms that were previously considered to belong to the same species (e.g., Neogoniolithon fosliei [Heydrich] Setchell \& L. R. Mason) (see Penrose 1992) were shown to be genetically distinct and their characteristics related to external morphology as the presence / absence of protuberances revealed to be useful in taxa delimitations (Kato et al. 2013). Locally, to ecologists and phycologists working with CCA populations, and understanding the anatomical and genetic differentiations, external morphology can be quite valuable (Bahia et al. 2014). Different CCA morphological states can play distinct roles within the reef structuration and succession (Steneck 1986). Thinner crusts are generally early colonizers and grow laterally (increasing its area) faster than thicker ones (Adey and Vassar 1975, Steneck 1985, Matsuda 1989).

Jesionek et al. (2016), based on molecular and morpho-anatomical data, identified and detailed nine CCA taxa along the Abrolhos reefs, including species reported to be coral killers such as Pneophyllum conicum (Keats et al. 1997) and Porolithon onkodes (Benzoni et al. 2011, 


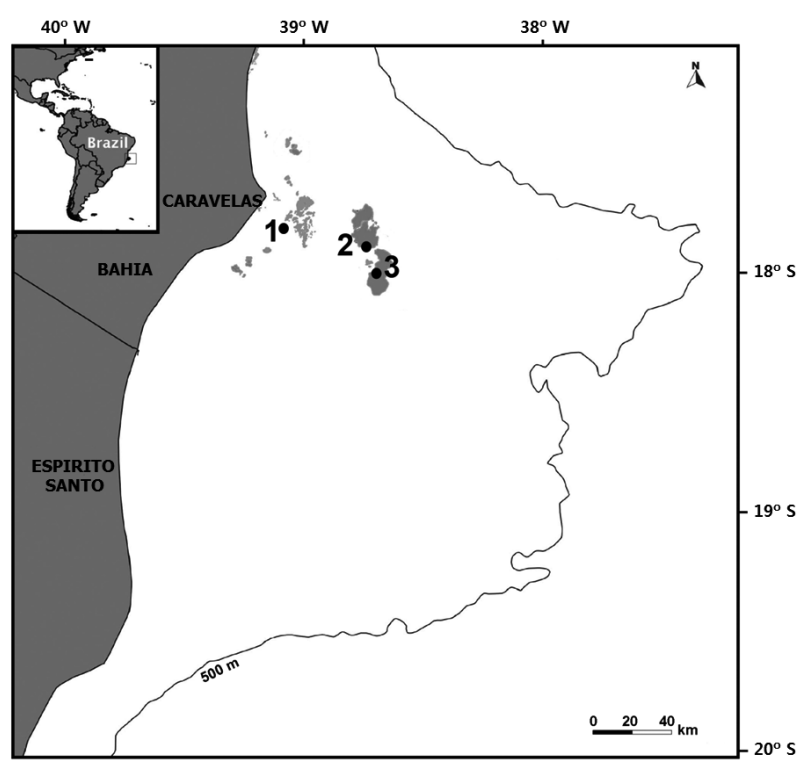

Fig. 1. Map of the Abrolhos Bank, eastern Brazil, showing study sites in the Abrolhos reefs. 1, Pedra de Leste; 2, Abrolhos Archipelago (AA); 3, Parcel dos Abrolhos (PAB2 and PAB3).

as Hydrolithon onkodes). These taxa exhibited stable growth-forms and visually distinctive characteristic, at least in Abrolhos Bank, that allowed us to recognize these species in the field (Jesionek et al. 2016).

The goal of this study is to determine the possible changes in the CCA communities on shallow reefs of Abrolhos Bank over a period of 10 years (2006-2015) and interpret the ecological significance of CCA to the local reefs. For this purpose, we evaluated the spatial and temporal patterns of the abundance of the most abundant local CCA species.

\section{MATERIALS AND METHODS}

\section{Study area}

Abrolhos Bank ( $16^{\circ} 40^{\prime}$ to $19^{\circ} 40^{\prime} \mathrm{S}, 37^{\circ} 20^{\prime}$ to $\left.39^{\circ} 10^{\prime} \mathrm{W}\right)$ has three main morphological types of shallow reefs that are distributed in inner and outer reef arcs: Type 1, isolated bank reefs of varied shapes, with dimensions that range from less than $1 \mathrm{~km}$ to approximately $20 \mathrm{~km}$ in length that occur nearshore (inner reef arc) at depths of 3-20 m; Type 2, shallow offshore ( $<10 \mathrm{~m}$ deep) fringing reefs that border the islands of the Abrolhos Archipelago (AA; outer reef arc); and Type 3, isolated mushroomshaped reef columns (up to $25 \mathrm{~m}$ high, with tops at 5-10 $\mathrm{m}$, and bases at 15-20 $\mathrm{m}$ depth) or "chapeirões" that form the Parcel dos Abrolhos (PAB; outer reef arc) (Leão and Kikuchi 2005, Moura et al. 2013). This study was carried out on the reef tops of Pedra de Leste (PL) on the inner reef arc and $\mathrm{AA}$ and $\mathrm{PAB}$ on the outer reef arc (Fig. 1), corresponding to some of the sites studied by FranciniFilho et al. (2013). The PL reefs $\left(17^{\circ} 47^{\prime} 01^{\prime \prime}\right.$ S, $39^{\circ} 03^{\prime} 05^{\prime \prime}$ $\mathrm{W})$ are the near-coast study site and are approximately 10-15 km away from the shore in the Parcel das Paredes. This latter consists of shallow large reef banks (Type 1) that are formed by pinnacles fused at the tops, and isolated patch reefs surrounding the fused structures. The AA $\left(17^{\circ} 57^{\prime} 45^{\prime \prime} \mathrm{S}, 38^{\circ} 41^{\prime} 43^{\prime \prime} \mathrm{W}\right)$ is located approximately $70 \mathrm{~km}$ east of the coast and is surrounded by fringing biogenic reefs that have developed over rocky substrata (reef Type 2). The PAB reefs, which are represented here

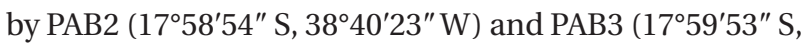
$\left.38^{\circ} 40^{\prime} 18^{\prime \prime} \mathrm{W}\right)$, are located approximately $75 \mathrm{~km}$ east of the coast. These reefs consist of isolated giant coral pinnacles, "chapeirões" that do not fuse to form bank reefs as they do in the coastal zone (reef Type 3 ). The outer reefs, $\mathrm{AA}$ and PAB (two sites), are located within a no-take marine protected area (Abrolhos Marine National Park) that was designated in 1983.

\section{Quantitative data}

Surveys were always carried out in summer (JanuaryMarch) to avoid seasonal influences. Between 2006 and 2015, the CCA assemblages were characterized using fixed photoquadrats in the reef flats $(\mathrm{n}=10$ per site). Each quadrat was composed of a mosaic of 15 high-resolution digital images obtained using Canon EOS 5D (Canon Inc., Tokyo, Japan) and Nikon D90 (Nikon Corp., Bangkok, Thailand) cameras with underwater housing totalling $0.4 \mathrm{~m}^{2}$. Quadrats were permanently delimited by fixed metal stakes and set at haphazard distances along 20-50 $\mathrm{m}$ transects. The relative cover of CCA assemblages was estimated from intercepts of 300 randomly distributed points per quadrat (i.e., 20 points per photograph) using the Coral Point Count with Excel Extensions Software (Kohler and Gill 2006). The frequencies of occurrence of CCA species were estimated by identifying the presence or absence of each CCA group and each species / complex using the 15 high-resolution digital images per quadrat $(\mathrm{n}=10)$ (archived and analysed in Adobe Photoshop Lightroom 5 software). Surveys from specific six years (2006, 2009, and 2012-2015) were selected for this study, as they had a sufficient number of high-quality photographs required for the analyses. 


\section{Identification methods}

The CCA species were identified in the images based on their typical external appearance (growth-form), as described in Jesionek et al. (2016). The details of the growth-forms used to distinguish the species are related to the thallus textures and protuberance patterns, as presented in Fig. 2. Growth-form terminology followed Woelkerling et al. (1993).

\section{Data analyses}

The differences in the relative covers of CCA assemblages and frequencies of occurrence of CCA species / complexes between sites and years were evaluated by means of a permutational multivariate ANOVA (PERMANOVA) that included one or two fixed factors. The analysed factors were site (PL, AA, PAB2, and PAB3) and year (2006, 2009, and 2012-2015).

Cluster analysis based on the Bray-Curtis coefficient was used to evaluate the relationship between sites / years and the frequencies of occurrence of the five identified taxa. Statistical analyses (PERMANOVA and Cluster) were carried out using PRIMER ver. 6 + PERMANOVA software (PRIMER-E Ltd., Ivybridge, UK). Pairwise comparisons were performed to identify the variations among levels and significant factors when there was a significant difference $(p<0.05)$. Correlations between frequencies of occurrence of each CCA species / complex were computed using Statistica ver. 7.0 (StatSoft, Inc., Tulsa, OK, USA).

\section{RESULTS}

\section{Characterization of the composition of CCA as- semblages}

Five dominant CCA taxonomic groups were identified belonging to Corallinales (Hydrolithon boergesenii [Foslie] Foslie / Porolithon onkodes complex, Pneophyllum conicum, and Lithophyllum kaiseri [Heydrich] Heydrich / Lithophyllum sp. complex), Hapalidiales (Melyvonnea erubescens), and Peyssonneliales (Peyssonnelia sp.). Brief descriptions of the external morphologies (growth forms) and some ecological observations are presented below for each analysed CCA group.

Hydrolithon boergesenii and Porolithon onkodes were found to occupy the same microhabitats and displayed similar growth forms, making them difficult to discriminate in digital images. For this reason, these species were pooled and quantified as a single morphotype called the H. boergesenii / P. onkodes morphological complex. The same occurred with the two local branched Lithophyllum species, Lithophyllum kaiseri, and Lithophyllum sp., which can currently be distinguished from only DNA sequences (Jesionek et al. 2016). For this reason, these two species were pooled and quantified as the L. kaiseri / Lithophyllum sp. morphological complex.

\section{Hydrolithon boergesenii (Foslie) Foslie and Poro- lithon onkodes (Heydrich) Foslie morphological complex}

Thalli are encrusting to lumpy and whitish or pink to purple in colour. Thallus surfaces were generally smooth and formed swollen protuberances that were contiguous or separated by slits (Figs 2E, 3E \& F). This morphotype is limited to shallow areas of the reef that are directly exposed to sunlight. This morphotype was commonly found overgrowing living hydrocorals, stony corals, and other CCA species. Borer holes are frequently seen at their thallus surfaces.

\section{Pneophyllum conicum (E. Y. Dawson) Keats, Y. M. Chamberlain \& M. Baba}

Thalli are pink to purple in colour with predominantly warty and sometimes encrusting growth-forms. Thallus surfaces are generally dominated by nodular and small warty protuberances (Fig. 2A) that are sometimes influenced by the substrate shape (Fig. 3A \& B). This species was found covering large areas of the top and walls of the reef from 2-15 m depth and often overgrowing living fire-corals (Millepora spp.), stony corals, and other CCA species.

\section{Lithophyllum kaiseri (Heydrich) Heydrich / Litho- phyllum sp. morphological complex}

Thalli are fruticose, pink to dark red in colour. Protuberances have a smooth surface, are cylindrical and frequently slightly compressed. Most protuberances terminate with blunt apices, and some are fused at the distal ends (Figs 2B \& 3C). This morphotype was found in shallow (2-5 $\mathrm{m}$ depth) exposed areas of the reef creating densely branched mounds that could reach more than 10 $\mathrm{cm}$ thick. Although some individuals can occasionally be seen growing over corals, the area occupied by an individual is relatively small when compared with the organism underneath. 


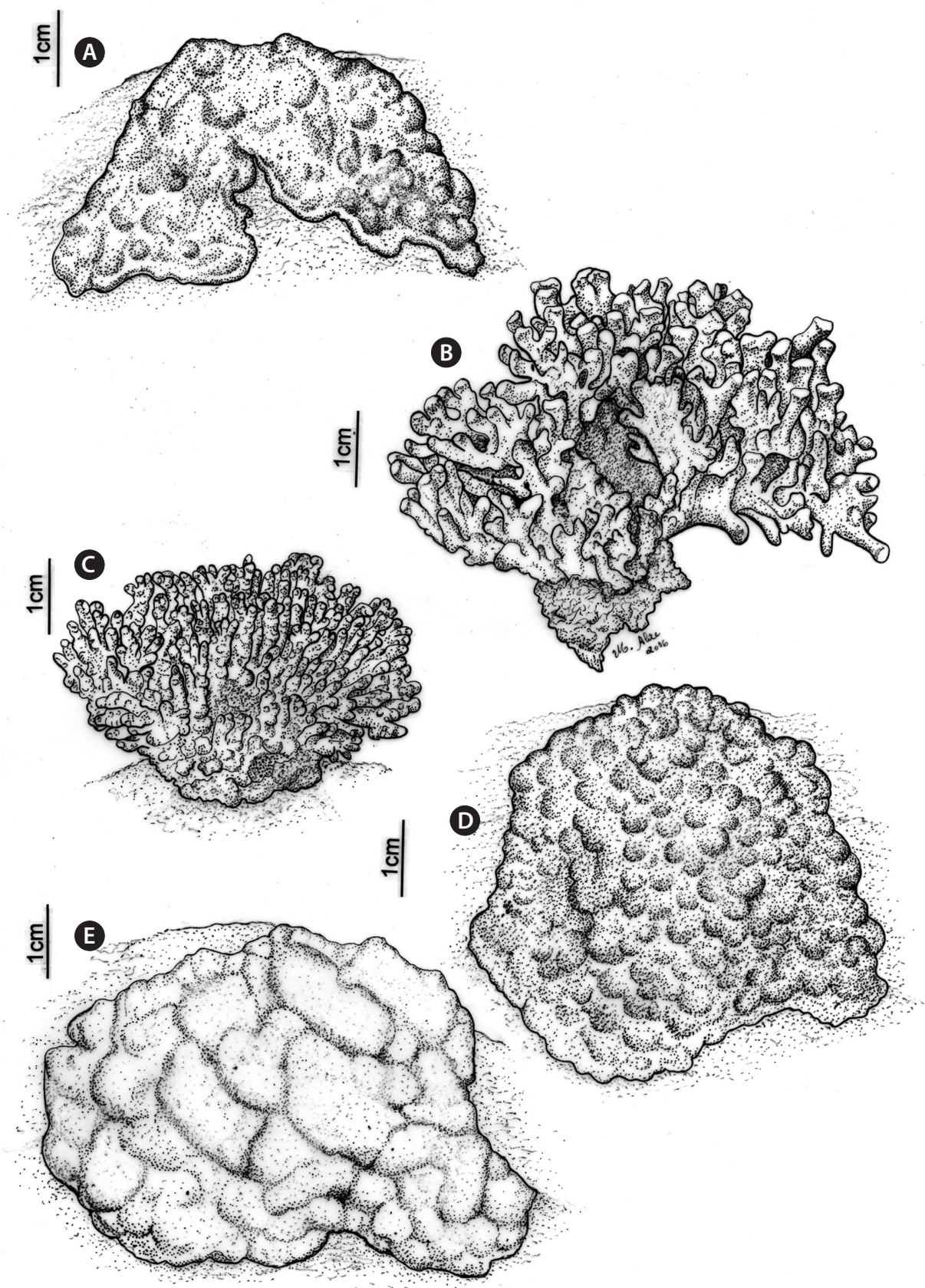

Fig. 2. Prevalent external appearance (growth-form) of the five most common taxonomic group of crustose calcareous algae found in the Abrolhos shallow reefs. (A) Pneophyllum conicum. (B) Lithophyllum kaiseri / Lithophyllum sp. complex. (C) Melyvonnea erubescens. (D) Peyssonnelia sp. (E) Hydrolithon boergesenii / Porolithon onkodes complex. Scale bars represent: A-E, $1 \mathrm{~cm}$.

\section{Melyvonnea erubescens (Foslie) Athanasiadis \& D. L. Ballantine}

Thalli are fruticose, pink to red in colour. Most protuberances are cylindrical with rounded apices (Figs 2C \& 3D) that are not compressed as in the Lithophyl- lum kaiseri / Lithophyllum sp. complex. This species was found in shallow (2-5 m depth) exposed areas of the reef. Although some individuals can occasionally be seen growing over corals, the area occupied by an individual is relatively small when compared with the organism underneath. 

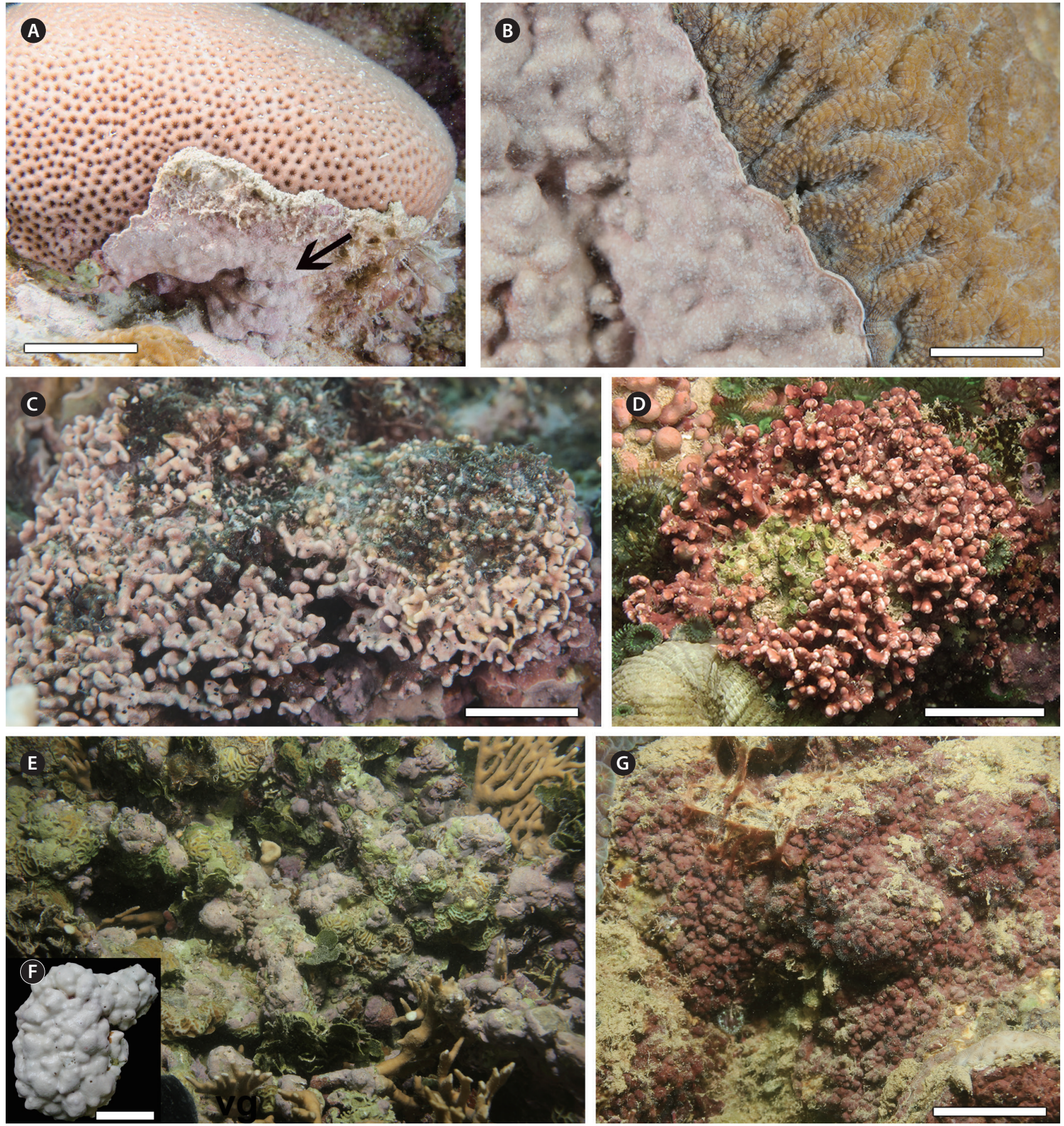

Fig. 3. In situ images of the five most common taxonomic group of crustose calcareous algae found in the Abrolhos shallow reefs. (A) Pneophyllum conicum (arrow) overgrowing the stony coral Siderastrea stellata. (B) Pneophyllum conicum (left side) growing on the stony coral Mussismilia braziliensis (right side). (C) Lithophyllum kaiseri / Lithophyllum sp. complex. (D) Melyvonnea erubescens. (E \& F) Hydrolithon boergesenii / Porolithon onkodes complex. (G) Peyssonnelia sp. partially covered by sediment. Scale bars represent: A, $10 \mathrm{~cm} ; B, C \& G, 3 \mathrm{~cm} ; D, 4 \mathrm{~cm} ; F, 2 \mathrm{~cm}$. 

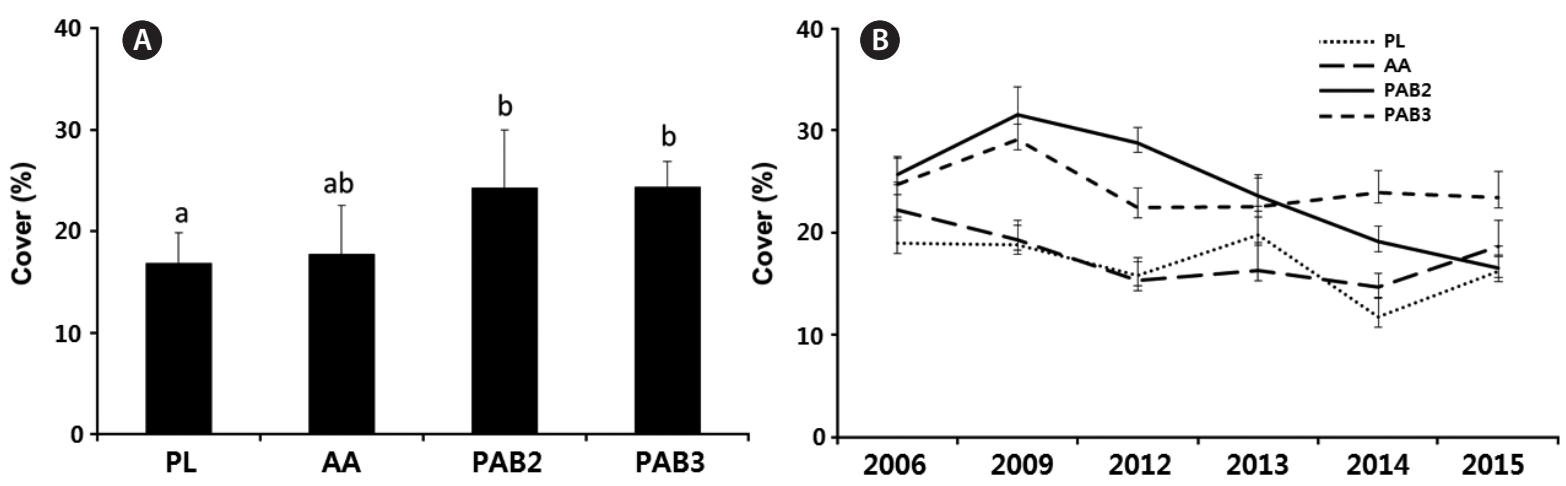

Fig. 4. Percentage cover of crustose calcareous algae (CCA) in the Abrolhos reefs. (A) CCA cover between sites considering all years. (B) CCA cover in each site during the years 2006, 2009, and 2012-2015. Data are mean \pm standard deviation ( $n=10$ per year). Different letters above bars indicate statistical differences $(p<0.05)$ of CCA cover obtained through pairwise tested after the PERMANOVA analysis. PL, Pedra de Leste; AA, Abrolhos Archipelago; PAB, Parcel dos Abrolhos; PERMANOVA, permutational multivariate ANOVA.

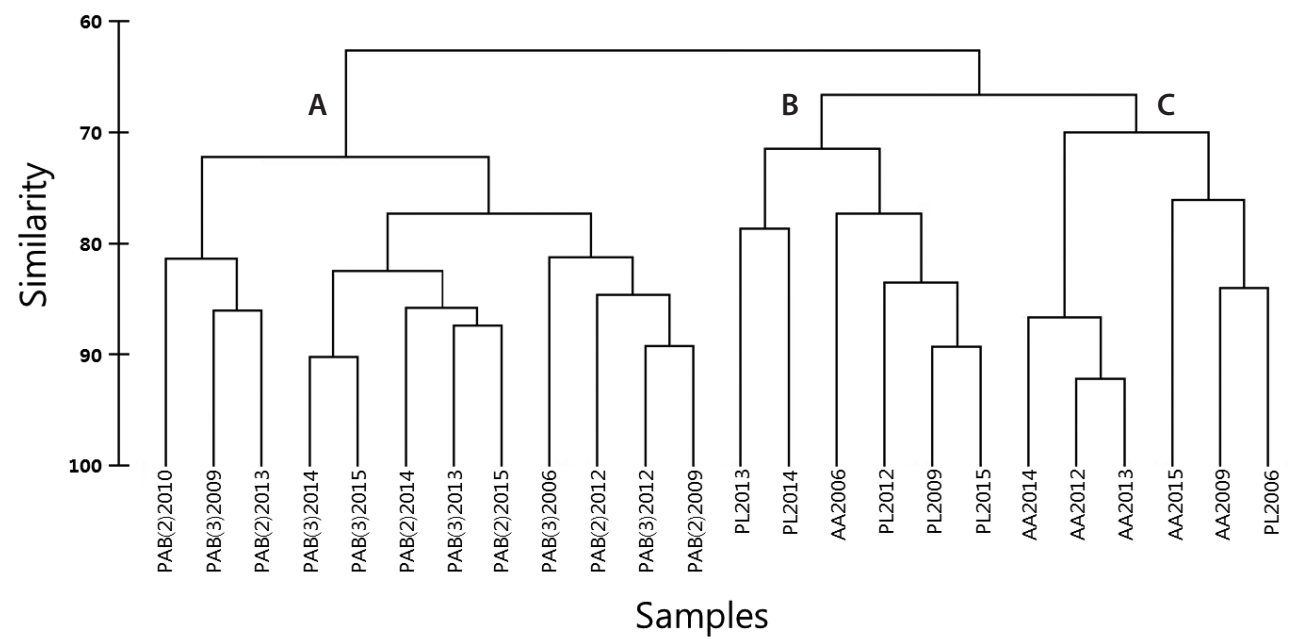

Fig. 5. Dendrogram resulted from the Cluster analysis between sites / years (24) and the frequency of occurrence of five identified taxa. Three main groups were detected, A-C.

\section{Peyssonnelia sp.}

Thalli are smooth warty to lumpy and dark red to brown in colour (Figs 2D \& 3G). This species was mostly found in shady areas, covering large areas of the tops and walls of a reef from 3-15 m depth.

\section{Percent cover of the CCA among sites and years}

The mean cover of CCA on the reef tops was estimated to be $20 \%$ (Fig. 4). Significant differences in the CCA coverages of sites were detected $(\mathrm{F}=17.349, \mathrm{p}<0.001)$ (Table 1). An interaction between site and year was obtained (PERMANOVA, $\mathrm{F}=1.6558, \mathrm{p}=0.03$ ) (Table 1), and the abundance of each year depended on the site. The
CCA abundance values on the outer reefs PAB2 $(24.1 \pm$ $5.7 \%)$ and PAB3 $(24.2 \pm 2.4 \%)$ were higher than those on the nearshore reefs (PL) $(16.6 \pm 2.9 \%)$. However, no differences in CCA cover between AA $(17.6 \pm 4.7 \%)$ and the other sites were observed (Fig. 4A). There was a reduction in coverage at PL in $2014(11.7 \pm 2.8 \%)$ and at PAB2 in $2014(19.1 \pm 2.5 \%)$ and 2015 (16.4 $\pm 2.0 \%)$ (Fig. 4B). Nevertheless, no changes over the years were seen in either AA (14.7 \pm 2.4 to $22.2 \pm 2.2 \%)$ and PAB3 $(22.4 \pm 2.8$ to 29.1 $\pm 2.4 \%)$.

\section{Structural patterns of CCA assemblages}

The cluster analysis of the 24 observations (sites / years) based on the five CCA taxa indicates a site simi- 
larity greater than $60 \%$ and that three major groups of sites were formed with $70 \%$ similarity (Fig. 5). Group A is formed by PAB2 and PAB3. Group B consisted of all PL samples, except PL 2006, which was in group C. Group C was formed by all analysed samples from AA, except for AA 2006, which was in group B (Fig. 5). The PERMANOVA indicated that the frequency of occurrence of CCA varied significantly among sites $(\mathrm{F}=7.823, \mathrm{p}<0.001)$, regardless of the year studied (Table 1). PL and AA were significantly different from PAB2 and PAB3 but were not different from each other.

\section{Frequency of occurrence of CCA species / com- plexes in different sites and years}

An interaction between the site and year factors for the frequency of occurrence of CCA species / complexes was obtained (PERMANOVA F = 2.2289, p < 0.001) (Table 1), indicating that temporal fluctuations in abundance varied among sites.

PL were characterized by greater frequencies of $P$. conicum (30.5\%), Peyssonnelia sp. (18\%) and the Hydrolithon boergesenii / Porolithon onkodes complex (12.8\%) over

Table 1. Results of multivariate analyzes (PERMANOVA) with two factors, testing the differences in coverage and frequency of occurrence of the crustose calcareous algae (CCA), varying depending on the site and year

\begin{tabular}{|c|c|c|c|c|}
\hline Group of organisms & Df & MS & $\mathbf{F}$ & p-value \\
\hline \multicolumn{5}{|l|}{ Coverage } \\
\hline \multicolumn{5}{|l|}{ CCA } \\
\hline Site & 3 & 5,084 & 17.359 & $<0.001$ \\
\hline Year & 5 & $1,391.8$ & 4.749 & $<0.001$ \\
\hline Site $\times$ year & 15 & 485.2 & 1.656 & $<0.050$ \\
\hline Residual & - & 293 & - & - \\
\hline \multicolumn{5}{|l|}{ Frequency of occurrence } \\
\hline \multicolumn{5}{|l|}{ CCA } \\
\hline Site & 3 & 6,643 & 7.823 & $<0.001$ \\
\hline Year & 7 & 570 & 0.819 & 0.457 \\
\hline Site $\times$ year & 16 & 1,459 & 1.769 & 0.067 \\
\hline Residual & - & 756.5 & - & - \\
\hline \multicolumn{5}{|l|}{ Species of CCA } \\
\hline Site & 3 & 9,456 & 15.929 & $<0.001$ \\
\hline Year & 7 & $1,874.7$ & 3.1582 & $<0.001$ \\
\hline Site $\times$ year & 16 & $1,323.1$ & 2.229 & $<0.001$ \\
\hline Residual & - & 593.6 & - & - \\
\hline \multicolumn{5}{|l|}{ Pneophyllum conicum } \\
\hline Site & 3 & 6,703 & 7.823 & 0.001 \\
\hline Year & 7 & 670 & 0.7819 & 0.645 \\
\hline Site $\times$ year & 16 & 1,259 & 1.469 & 0.077 \\
\hline Residual & - & 856.8 & - & - \\
\hline \multicolumn{5}{|c|}{ Hydrolithon boergesenii / Porolithon onkodes complex } \\
\hline Site & 3 & 12,111 & 23.173 & $<0.001$ \\
\hline Year & 4 & $4,786.9$ & 9.159 & $<0.001$ \\
\hline Site $\times$ year & 12 & $1,861.8$ & 3.562 & $<0.001$ \\
\hline Residual & - & 522.6 & - & - \\
\hline \multicolumn{5}{|c|}{ Lithophyllum kaiseri / Lithophyllum sp. complex } \\
\hline Site & 3 & 12,350 & 18.037 & $<0.001$ \\
\hline Year & 7 & $2,032.2$ & 2.968 & $<0.001$ \\
\hline Site $\times$ year & 13 & 5,548 & 8.103 & $<0.001$ \\
\hline Residual & - & 684.7 & - & - \\
\hline \multicolumn{5}{|l|}{ Melyvonnea erubescens } \\
\hline Site & 3 & $3,417.2$ & 4.698 & $<0.001$ \\
\hline Year & 7 & $4,537.5$ & 6.239 & $<0.001$ \\
\hline Site $\times$ year & 16 & $2,673.3$ & 3.675 & $<0.001$ \\
\hline Residual & - & 727.3 & - & - \\
\hline \multicolumn{5}{|l|}{ Peyssonnelia sp. } \\
\hline Site & 3 & $5,235.6$ & 7.533 & $<0.001$ \\
\hline Year & 5 & $1,048.7$ & 1.509 & 0.153 \\
\hline Site $\times$ year & 14 & 834.7 & 1.201 & 0.238 \\
\hline Residual & - & 695 & - & - \\
\hline
\end{tabular}

Significant differences are highlighted in bold.

PERMANOVA, permutational multivariate ANOVA; Df, degrees of freedom; MS, mean square. 

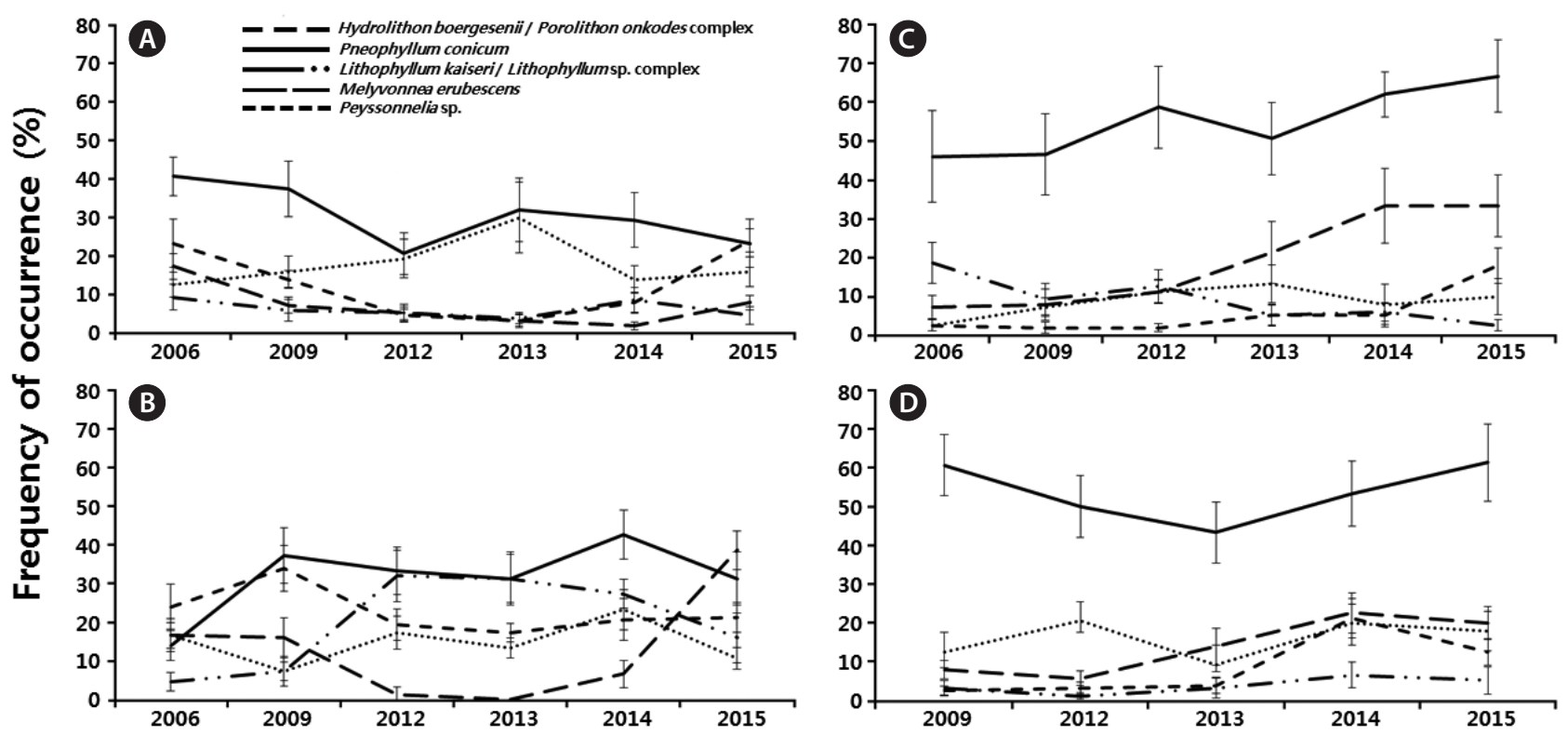

Fig. 6. Frequency of occurrence of Hydrolithon boergesenii / Porolithon onkodes complex, Pneophyllum conicum, Lithophyllum kaiseri / Lithophyllum sp. complex, Melyvonnea erubescens, and Peyssonnelia sp. in Pedra de Leste (A), Abrolhos Archipelago (B), Parcel dos Abrolhos (PAB) 3 (C), and PAB2 (D) during the years 2006, 2009, and 2012-2015. Data are mean \pm standard deviation ( $n=10$ per year).

the years (Fig. 6A). P. conicum was the most frequent CCA on the PL reef flat, and no changes in frequency over time were observed. The occurrence of the Hydrolithon boergesenii / Porolithon onkodes complex oscillated over the years, and it was more frequent in 2006 and 2015 (23.3 and $24 \%$, respectively). The occurrence of Melyvonnea erubescens decreased over the years, and the L. kaiseri / Lithophyllum sp. complex was the least frequent CCA on the PL reef flat, with a frequency of $6.3 \%$ (Fig. 6A).

The AA (Fig. 6B) was characterized by high frequencies of P. conicum (31.6\%), the Hydrolithon boergesenii I Porolithon onkodes complex (22.7\%) and the L. kaiseri / Lithophyllum sp. complex (19.7\%) over the years (Fig. 6B). The frequency of P. conicum, as well as the frequencies of Peyssonnelia sp. and the Hydrolithon boergesenii I Porolithon onkodes complex, did not change over time.

The PAB sites (PAB2 and PAB3) were characterized by the highest frequency of P. conicum, with frequencies of occurrence greater than $53 \%$ over the years (Fig. $6 C$ \& D). The lowest frequency was recorded for the Hydrolithon boergesenii / Porolithon onkodes complex (5.8\%, PAB3). However, the frequency of occurrence of this taxon increased over time, reaching $21.3 \%$ (PAB2, 2014) and 18\% (PAB3, 2015). The occurrence of Melyvonnea erubescens increased over time, becoming more frequent in 2015 at PAB2 (20\%) (Fig. 6D) and PAB3 (33.3\%) (Fig. 6C).

\section{DISCUSSION}

Jesionek et al. (2016) identified nine CCA taxa from the Abrolhos reefs, namely: Hydrolithon boergesenii, Lithophyllum kaiseri, Lithophyllum sp., Pneophyllum conicum, Porolithon onkodes, Lithophyllum prototypum (Foslie) Foslie, Melyvonnea erubescens, Lithothamnion crispatum Hauck, and Sporolithon ptychoides Heydrich. Among these taxa, we were able to identify and quantify the most abundant and conspicuous CCA species or morphological complexes based on their typical external appearances / growth-form (Table 2), in addition to Peyssonnelia sp. (not identified in Jesionek et al. 2016, but reported in nearby reefs by Mariath et al. 2013). Most CCA taxa that were recorded in the present study are commonly found in tropical and subtropical upper fore-reefs of the Indo-Pacific and / or Caribbean (Matsuda 1989, Keats et al. 1997, Littler and Littler 2000, Maneveldt and Keats 2014, Sissini et al. 2014, Hernandez-Kantun et al. 2016, Rösler et al. 2016). Although the importance of CCA as tropical reef builders is well known, relatively few species are involved in reef-building processes. In large tropical oceanic areas, only Hydrolithon, Porolithon, Lithophyllum, Neogoniolithon, Pneophyllum, Mesophyllum, Lithothamnion, and Sporolithon species have been recognized as important reef builders and consolidators (Johansen 1981, Littler and Littler 2000, Abbot et al. 2012). 
The Abrolhos Bank reef communities have been characterized by extensive CCA cover. Villaça and Pitombo (1997) found total CCA coverages of $4-36 \%$ in the oceanic (outer) and nearshore (inner) reefs of Abrolhos. Other research has shown different patterns of CCA cover based on studies restricted to the AA reefs, such as Figueiredo (1997), who recorded 32-79\% cover with Lithothamnion, Lithophyllum, Sporolithon, and Porolithon as the most abundant genera. Figueiredo and Steneck (2002) recorded $2-15 \%$ cover of corallines living in shallow zones with little fleshy algae, and the massive and complexly branched species of Porolithon and Lithophyllum were predominant. Figueiredo (2006) found $3-40 \%$ cover and Tâmega and Figueiredo (2007) found $10-20 \%$ cover on a sunlit reef edge where the CCA distribution was characterized by abundance of the flat thallus of Porolithon onkodes (as Porolithon pachydermum) in relation to the branched crust of Lithophyllum kaiseri (as Lithophyllum congestum) (likely also referring to what Jesionek et al. 2016 considered Lithophyllum sp.).

In the present study, the total mean coverage of CCA on the Abrolhos reef tops was $20 \%$, which is approximately double what was determined by Francini-Filho et al. (2013) in 2003-2008 (12.1\%) for five shallow Abrolhos reef sites (including PAB, PL, and AA). This result indicates that the abundance of CCA increased on the Abrolhos reefs from 2003 to 2015. The high frequency of the thin species P. conicum on the PAB2 / PAB3 pinnacles was likely responsible for this increase in total CCA cover. Francini-Filho et al. (2013) observed that the benthic communities in these study sites are dominated by algal turfs $(56 \%)$ followed by CCA (12.1\%). In many Caribbean and Pacific coral reefs, algal turfs almost always dominate the reef community, followed by corals or macroalgae, depending on the reef type; however, CCA is likely underestimated and would balance coral cover in terms of importance (Adey 1998). Fabricius and De'ath (2001) found that CCA cover on the Great Barrier Reef is related to the sedimentary environment, being relatively higher on outer reefs with low sediment deposits. In this way, the higher CCA cover on the outer reefs PAB2 / PAB3 than that observed on PL may somehow be related to the lower terrigenous sediment deposits on these sites (Reis et al. 2016).

In the Hawaiian Archipelago, Adey et al. (1982) identified a total of 25 CCA species in 10 genera that were collected from an intertidal area to a depth of approximately $50 \mathrm{~m}$, where Pneophyllum conicum and Porolithon onkodes were the most frequent CCA (19\% of the specimens collected). However, in shallow water, P. onkodes tends to dominate along with the branched Lithophyllum kotschyanum Unger (Adey et al. 1982). In the Caribbean, Porolithon onkodes (as P. pachydermum) and Lithophyllum kaiseri (as L. congestum) occur in the same habitats (Adey 1975, Steneck and Adey 1976). Borings through several high ridges in St. Croix, U.S. Virgin Islands indicated that Porolithon onkodes (as P. pachydermum) and Lithophyllum kaiseri (as L. congestum) were the dominant Holocene builders of these ridges (Adey 1975). More recently, Dean et al. (2015) identified a total of 30 CCA

Table 2. Crustose calcareous algae species analyzed in this study and their respective growth-form in Brazil considering different environments

\begin{tabular}{|c|c|c|c|c|}
\hline Taxon & $\begin{array}{l}\text { Brazilian } \\
\text { specimens } \\
\text { growth-form }\end{array}$ & Habitat & Sources & $\begin{array}{l}\text { Type (holo, iso } \\
\text { or lectotype) } \\
\text { growth-form }\end{array}$ \\
\hline \multicolumn{5}{|l|}{ Corallinales } \\
\hline $\begin{array}{l}\text { Hydrolithon boergesenii } \\
(=\text { Hydrolithon reinboldii })\end{array}$ & $\begin{array}{l}\text { Encrusting } \\
\text { to lumpy }\end{array}$ & $\begin{array}{l}\text { Rocky shores, } \\
\text { coralgal reefs }\end{array}$ & $\begin{array}{l}\text { Tâmega et al. (2015), Jesionek et al. } \\
\text { (2016), this study }\end{array}$ & $\begin{array}{l}\text { Lumpy (Maneveldt } \\
\text { 2005) }\end{array}$ \\
\hline $\begin{array}{l}\text { Lithophyllum kaiseri / Lithophyllum sp. } \\
\text { complex (as Lithophyllum congestum) }\end{array}$ & Fruticose & $\begin{array}{l}\text { Rocky shores, } \\
\text { coralgal reefs }\end{array}$ & $\begin{array}{l}\text { Figueiredo and Steneck (2002), } \\
\text { Tâmega et al. (2014), Jesionek et al. } \\
\text { (2016), this study }\end{array}$ & $\begin{array}{l}\text { Fruticose (Hernan- } \\
\text { dez-Kantun et al. } \\
2016 \text { ) }\end{array}$ \\
\hline Pneophyllum conicum & $\begin{array}{l}\text { Encrusting } \\
\text { to warty }\end{array}$ & Coralgal reefs & $\begin{array}{l}\text { Mariath et al. (2012), Jesionek et al. } \\
\text { (2016), this study }\end{array}$ & $\begin{array}{l}\text { Encrusting (Keats } \\
\text { et al. 1997) }\end{array}$ \\
\hline Porolithon onkodes & $\begin{array}{l}\text { Encrusting } \\
\text { to lumpy }\end{array}$ & $\begin{array}{l}\text { Coralgal reefs, } \\
\text { atoll }\end{array}$ & $\begin{array}{l}\text { Villas-Boas et al. (2005), Mariath } \\
\text { (2013), Tâmega et al. (2014), } \\
\text { Jesionek et al. (2016), this study }\end{array}$ & $\begin{array}{l}\text { Encrusting } \\
\text { (Maneveldt and } \\
\text { Keats 2014) }\end{array}$ \\
\hline \multicolumn{5}{|l|}{ Hapalidiales } \\
\hline \multirow[t]{2}{*}{$\begin{array}{l}\text { Melyvonnea erubescens } \\
\text { (as Mesophyllum erubescens) }\end{array}$} & $\begin{array}{l}\text { Fruticose } \\
\text { to warty }\end{array}$ & $\begin{array}{l}\text { Rocky shore, } \\
\text { rhodolith beds, } \\
\text { coralgal reefs }\end{array}$ & $\begin{array}{l}\text { Foslie (1900), Horta et al. (2011), } \\
\text { Bahia (2014), Sissini et al. (2014) }\end{array}$ & $\begin{array}{l}\text { Fruticose (Sissini } \\
\text { et al. 2014) }\end{array}$ \\
\hline & Fruticose & Coralgal reefs & $\begin{array}{l}\text { Nunes et al. 2008, Jesionek et al. } \\
\text { (2016), this study }\end{array}$ & \\
\hline
\end{tabular}


species among 12 genera on the Great Barrier Reef. The most abundant species was $P$. onkodes, which was present in $66.9 \%$ of transects. The next most abundant species were Pneophyllum conicum (as Paragoniolithon conicum sensu Adey et al. 1982) (54.3\%) and Hydrolithon boergesenii (as H. reinboldii) (36.0\%). Differences in CCA abundance were observed across shelf position, with outer-shelf reefs exhibiting higher abundances than midshelf and inner-shelf reefs (Dean et al. 2015).

The cluster analysis and PERMANOVA revealed that CCA assemblages and abundances are strongly influenced by the site / reef type. Recruitment (settlement and early survival), growth, succession, competition, and disturbance (physical and biological) are important processes that can affect the distribution and abundance of CCA (Steneck 1986). These factors likely act differently on the three different studied reef types whose morphology seems to be related to the underlying substratum (beach rock, Precambrian bedrock, older reefs, etc.), the prevailing hydraulic and sedimentation regime, and the relative position of the reef to the current and past sea level (Kikuchi et al. 2003, Bastos et al. 2015). The CCA assemblages at the $\mathrm{PAB}$ sites were markedly different from those at AA and PL, particularly due to the high frequency of P. conicum over the years. Moreover, PAB is characterized by a unique reef type (Type 3) that is formed by mushroomshaped reef pinnacles that are exposed to sunlight and have shallow horizontal tops (approximately 1-50 m extension, 2-6 m depth) and deeper vertical walls (approximately 1-25 m high) (Leão and Kikuchi 2001). Jesionek et al. (2016) and our personal observations indicate that P. conicum thrives on both walls and tops of pinnacles, while most other CCA species have limited growth at the tops of pinnacles. Thus, we hypothesize that the pinnacle walls serve as refugia and seeding sources for $P$. conicum at the pinnacle tops.

The calcareous crusts that dominate the shallow Abrolhos reefs can be operationally defined as predominantly thin $(\leq 500 \mu \mathrm{m}$ in thickness) (P. conicum), thick ( $>500 \mu \mathrm{m}$ in thickness) (Hydrolithon boergesenii / Porolithon onkodes complex and Peyssonnelia sp.) and / or branched (Lithophyllum kaiseri / Lithophyllum sp. complex and Melyvonnea erubescens) (Steneck 1986, Mariath et al. 2012, 2013, Jesionek et al. 2016). Sites where the primary substrate is often exposed, such as in intensely disturbed habitats, are commonly dominated by thin, fast growing crusts that either recruit as spores or expand laterally (Adey and Vassar 1975, Steneck 1986). In general, late colonizers are more expansive, thicker and / or branched (Adey and Vassar 1975, Steneck 1986). Adey and Vassar (1975) noted that in areas of high wave energy in St. Croix, U.S. Virgin Islands, where the activities of grazing organisms are greatly reduced, the climax species Lithophyllum kaiseri (as L. congestum) and Porolithon onkodes (as P. pachydermum) are capable of building intertidal algal ridges.

On a reef flat $150 \mathrm{~km}$ north of the Abrolhos reefs, $P$. conicum was the CCA with the highest abundance, which was twice that of Porolithon onkodes (as P. pachydermum) (Mariath et al. 2013). The high frequency of $P$. conicum that was observed in Abrolhos, especially on the pinnacles of PAB, can pose a threat to the health of reefs. P. conicum is widespread in the Indo-Pacific where it has been demonstrated to overgrow and kill live corals (Antonius 2001). During a coral reef health survey in Mauritius, $80 \%$ of the corals were found to be covered to some degree by P. conicum. Many large corals were totally enveloped by two, three, or more contiguous thalli, some measuring almost $1 \mathrm{~m}$ in diameter (Antonius 2001). In Hawaii, Pneophyllum conicum (as Paragoniolithon conicum) occurs on a variety of "coralgal" substrates, and it appears to prefer the sides of finger corals, and may eventually kill living coral by gradually growing up from below (Adey et al. 1982). On the other hand, this alga may be instrumental in reef ecology as it provides smooth surfaces for the attachment and recolonization by other organisms. Keats et al. (1997) observed young corals and other sedentary organisms attached to the surfaces of older $P$. conicum thalli.

The high frequency of thin P. conicum on the reefs of Abrolhos Bank can be related to the favourable competitive attributes of this species in reef succession. Pneophyllum conicum (as Paragoniolithon conicum) was reported to have the fastest lateral growth rates (mean of 0.9 $\pm 1.1 \mathrm{~mm} \mathrm{~m}^{-1}$ ) and achieved dominance by competitive overgrowing interactions with other CCA in Japan (Matsuda 1989). Similarly, Mariath et al. (2013) demonstrated a competitive superiority of $P$. conicum in overgrowing interactions in reefs near Abrolhos. In addition, the high frequency of P. conicum on the Abrolhos Bank may be related to a reduction in fitness of thick CCA. Reis et al. (2016) detected a marine heat wave during the summer of 2013-2014 at the same studied sites in Abrolhos Bank, and this heat wave was positively correlated with the increase in turf cover. This interspecific competition, which is strongly influenced by heat waves, should be an important stressor for CCA species.

Multiple stressors have been described to act on the shallow Abrolhos reefs. These stressors include oversedimentation (Dutra et al. 2006, Segal and Castro 2011), 
overfishing (Francini-Filho and Moura 2008), water quality changes (Bruce et al. 2012) and coral bleaching events that are related to the increase in the frequency of marine heatwaves (Reis et al. 2016). Associated with this, a possible epizoism syndrome by $P$. conicum is another factor that could lead to the decline of coral cover on the Abrolhos reefs, which could reduce habitat complexity. As these changes can accelerate the degradation process in the Abrolhos reef communities, they need to be monitored.

The present study reveals that the CCA cover nearly doubled on the shallow Abrolhos reefs from 2003-2008 to 2006-2015, and the CCA flora is predominantly composed of five taxonomic groups belonging to Corallinales, Hapalidiales, and Peyssonneliales. The local specific abundance of CCA slightly fluctuated over the years and was strongly influenced by the sites / reef types where they occur. The species Pneophyllum conicum dominated the local CCA flora in the last decade, which arouses environmental concern for its monitoring due to its coral-killing potential. The information obtained in this study contributes to our understanding of the ecology of the key calcifying components of the Abrolhos reefs and provides a useful baseline for exploring the responses of CCA to future environmental changes. Thus, the continuity of long-term monitoring programmes in these large coral reefs of the South Atlantic is of paramount importance.

\section{ACKNOWLEDGEMENTS}

We thank the team from the Abrolhos Marine National Park/ICMBio and Marine Program Group of Conservation International Brazil for support during the field work. Financial support was provided by the PELD and Mudanças Climáticas scientific programmes of the Brazilian National Science Agency (CNPq), Brazilian IODP Program (CAPES/MEC), P\&D Program ANP/Brasoil (48610.011015/2014-55) and research grants to GMAF from FAPERJ and CNPq. Thanks are due to FAPERJ for providing a postdoctoral fellowship grant to the second author (RGB).

\section{REFERENCES}

Abbott, I. A., Riosmena-Rodríguez, R., Kato, A., Squair, C. A., Michael, T. S. \& Smith, C. M. 2012. Hawaiian crustose coralline algae: a survey of common species. Hawaii
Botanical Science Paper No. 47. University of Hawaii at Manoa, Honolulu, HI, 58 pp.

Adey, W. H. 1975. The algal ridges and coral reefs of St. Croix: their structure and Holocene development. Atoll. Res. Bull. 187:1-67.

Adey, W. H. 1998. Coral reefs: algal structured and mediated ecosystems in shallow, turbuleny, alkaline waters. J. Phycol. 34:393-406.

Adey, W. H., Townsend, R. A. \& Boykins, W. T. 1982. The crustose coralline algae (Rhodophyta: Corallinacea) of the Hawaiian Islands. Smithson. Contrib. Mar. Sci. 15:1-74.

Adey, W. H. \& Vassar, J. M. 1975. Colonization, succession and growth rates of tropical coralline algae (Rhodophyta, Cryptonemiales). Phycologia 14:55-69.

Amado-Filho, G. M., Moura, R. L., Bastos, A. C., Salgado, L. T., Sumida, P. Y., Guth, A. Z., Francini-Filho, R. B., PereiraFilho, G. H., Abrantes, D. P., Brasileriro, P. S., Bahia, R. G., Leal, R. N., Kaufman, L., Kleypas, J. A., Farina, M. \& Thompson, F. L. 2012. Rhodolith beds are major $\mathrm{CaCO}_{3}$ bio-factories in the Tropical South West Atlantic. PLoS ONE 7:e35171.

Antonius, A. 2001. Pneophyllum conicum, a coralline red alga causing coral reef-death in Mauritius. Coral Reefs 19:418.

Babcock, R. \& Mundy, C. 1996. Coral recruitment: consequences of settlement choice for early growth and survivorship in two scleractinians. J. Exp. Mar. Biol. Ecol. 206:179-201.

Bahia, R. G. 2014. Algas coralináceas formadoras de rodolitos da plataforma continental tropical e ilhas oceânicas do Brasil: levantamento florístico e taxonomia. Ph.D. dissertation, Escola Nacional de Botânica Tropical, Rio de Janeiro, $221 \mathrm{pp}$.

Bahia, R. G., Amado-Filho, G. M., Maneveldt, G. W., Adey, W. H., Johnson, G., Marins, B. V. \& Longo, L. L. 2014. Sporolithon tenue sp. nov. (Sporolithales, Corallinophycidae, Rhodophyta): a new rhodolith-forming species from the tropical southwestern Atlantic. Phycol. Res. 62:44-54.

Ballantine, D. L. \& Ruiz, H. 2011. Metapeyssonnelia milleporoides, a new species of coral-killing red alga (Peyssonneliaceae) from Puerto Rico, Caribbean Sea. Bot. Mar. 54:47-51.

Bastos, A. C., Quaresma, V. S., Marangoni, M. B., D'Agostini, D. P., Bourguignon, S. N., Cetto, P. H., Silva, A. E., AmadoFilho, G. M., Moura, R. L. \& Collins, M. 2015. Shelf morphology as an indicator of sedimentary regimes: a synthesis from a mixed siliciclastic-carbonate shelf on the eastern Brazilian margin. J. S. Am. Earth Sci. 63:125-136.

Benzoni, F., Basso, D., Caragnano, A. \& Rodondi, G. 2011. Hydrolithon spp. (Rhodophyta, Corallinales) overgrow 
live corals (Cnidaria, Scleractinia) in Yemen. Mar. Biol. 158:2419-2428.

Bittner, L., Payri, C. E., Maneveldt, G. W., Couloux, A., Cruaud, C., de Reviers, B. \& Le Gall, L. 2011. Evolutionary history of the Corallinales (Corallinophycidae, Rhodophyta) inferred from nuclear, plastidial and mitochondrial genomes. Mol. Phylogenet. Evol. 61:697-713.

Broom, J. E. S., Hart, D. R., Farr, T. J., Nelson, W. A., Neill, K. F., Harvey, A. S. \& Woelkerling, W. J. 2008. Utility of $p s b$ A and nSSU for phylogenetic reconstruction in the Corallinales based on New Zealand taxa. Mol. Phylogenet. Evol. 46:958-973.

Bruce, T., Meirelles, P. M., Garcia, G., Paranhos, R., Rezende, C. E., Moura, R. L., Filho, R. F., Coni, E. O. C., Vasconcelos, A. T., Amado-Filho, G., Hatay, M., Schmieder, R., Edwards, R., Dinsdale, E. \& Thompson, F. L. 2012. Abrolhos Bank reef health evaluated by means of water quality, microbial diversity, benthic cover, and fish biomass data. PLoS ONE 7:e36687.

Carro, B., Lopez, L., Pena, V., Barbara, I. \& Barreiro, R. 2014. DNA barcoding allows the accurate assessment of European maerl diversity: a Proof-of-Concept study. Phytotaxa 190:176-189.

Dean, A. J., Steneck, R. S., Tager, D. \& Pandolfi, J. M. 2015. Distribution, abundance and diversity of crustose coralline algae on the Great Barrier Reef. Coral Reefs 34:581-594.

Díaz-Pérez, L., Rodríguez-Zaragoza, F. A., Ortiz, M., CupulMagaña, A. L., Carriquiry, J. D., Ríos-Jara, E., RodríguezTroncoso, A. P. \& García-Rivas, M. C. 2016. Coral reef health indices versus the biological, ecological and functional diversity of fish and coral assemblages in the Caribbean Sea. PLoS ONE 11:e0167252.

Dutra, L. X. C., Kikuchi, R. K. P. \& Leão, Z. M. A. N. 2006. Effects of sediment accumulation on reef corals from Abrolhos, Bahia, Brazil. J. Coast. Res. 39:633-638.

Eckrich, C. E., Engel, M. S. \& Peachey, R. B. J. 2011. Crustose, calcareous algal bloom (Ramicrusta sp.) overgrowing scleractinian corals, gorgonians, a hydrocoral, sponges, and other algae in Lac Bay, Bonaire, Dutch Caribbean. Coral Reefs 30:131.

Fabricius, K. \& De'ath, G. 2001. Environmental factors associated with the spatial distribution of crustose coralline algae on the Great Barrier Reef. Coral Reefs 19:303-309.

Figueiredo, M. A. O. 1997. Colonization and growth of crustose coralline algae in Abrolhos, Brazil. In Lessios, H. A. \& Macintyre, I. G. (Eds.) Proceedings of the 8th International Coral Reef Symposium, Smithsonian Tropical Research Institute, Panama, pp. 689-694.

Figueiredo, M. A. O. 2006. Diversity of macrophytes in the Abrolhos Bank, Brazil. In Dutra, G. F., Allen, G. R., Wer- ner, T. \& McKenna, S. A. (Eds.) A Rapid Marine Biodiversity Assessment of the Abrolhos Bank, Bahia, Brazil. RAP Bulletin of Biological Assessment, Vol. 38. Conservation International, Arlington, VA, pp. 67-74.

Figueiredo, M. A. O. \& Steneck, R. S. 2002. Floristic and ecological studies of crustose coralline algae on Brazil's Abrolhos reefs. In Kasim, M. (Ed.) Proceedings of the 9th International Coral Reef Symposium, Ministry of Environment, Indonesian Institute of Sciences, International Society for Reef Studies, Bali, pp. 493-498.

Foslie, M. 1900. New or critical calcareous algae. Kongel. Norske. Vidensk. Selsk. Skr. 5:1-34.

Foster, M. S. 1975. Algal succession in a Macrocystis pyrifera forest. Mar. Biol. 32:313-329.

Francini-Filho, R. B., Coni, E. C. O., Meirelles, P. M., AmadoFilho, G. M., Thompson, F. L., Pereira-Filho, G. H., Bastos, A. C., Abrantes, D. P., Ferreira, C. M., Gibran, F. Z., Güth, A. Z., Sumida, P. Y. G., Oliveira, N. L., Kaufman, L., Minte-Vera, C. V. \& Moura, R. L. 2013. Dynamics of coral reef benthic assemblages of the Abrolhos Bank, Eastern Brazil: inferences on natural and anthropogenic drivers. PLoS ONE 8:e54260.

Francini-Filho, R. B. \& Moura, R. L. 2008. Dynamics of fish assemblages on coral reefs subjected to different management regimes in the Abrolhos Bank, eastern Brazil. Aquat. Conserv. Mar. Freshw. Ecosyst. 18:1166-1179.

Harrington, L., Fabricius, K., De’ath, G. \& Negri, A. 2004. Recognition and selection of settlement substrata determine post-settlement survival in corals. Ecology 85:3428-3437.

Harvey, As., Woelkerling, W. J., Farr, T., Neill, K. \& Nelson, W. A. 2005. Coralline algae of central New Zealand: an identification guide to common 'crustose' species. NIWA Information Series No. 57. National Institute of Water and Atmospheric Research, Wellington, 145 pp.

Hernandez-Kantun, J. J., Gabrielson, P., Hughey, J. R., Pezzolesi, L., Rindi, F., Robinson, N. M., Peña, V., RiosmenaRodríguez, R., Le Gall, L. \& Adey, W. 2016. Reassessment of branched Lithophyllum spp. (Corallinales, Rhodophyta) in the Caribbean Sea with global implications. Phycologia 55:619-639.

Horta, P. A., Scherner, F., Bouzon, Z. L., Riosmena-Rodrígues, R. \& Oliveira, E. C. 2011. Morphology and reproduction of Mesophyllum erubescens (Foslie) Me. Lemoine (Corallinales, Rhodophyta) from Southern Brazil. Rev. Bras. Bot. 34:125-134.

Jesionek, M. B., Bahia, R. G., Hernández-Kantún, J., Adey, W. H., Yoneshigue-Valentin, Y., Longo, L. L. \& Amado-Filho, G. M. 2016. A taxonomic account of non-geniculate coralline algae (Corallinophycidae, Rhodophyta) from 
shallow reefs of the Abrolhos Bank, Brazil. Algae 31:317340 .

Johansen, H. W. 1981. Coralline algae: a first synthesis. CRC Press, Boca Raton, FL, 239 pp.

Kato, A., Baba, M. \& Suda, S. 2013. Taxonomic circumscription of heterogeneous species Neogoniolithon brassicaflorida (Corallinales, Rhodophyta) in Japan. Phycol. Res. 61:15-26.

Keats, D. W., Chamberlain, Y. M. \& Baba, M. 1997. Pneophyllum conicum (Dawson) comb. nov. (Rhodophyta, Corallinaceae), a widespread Indo-Pacific non-geniculate coralline alga that overgrows and kills live coral. Bot. Mar. 40:263-279.

Kendrick, G. A. 1991. Recruitment of coralline crusts and filamentous turf algae in the Galapagos archipelago: effect of simulated scour, erosion and accretion. J. Exp. Mar. Biol. Ecol. 147:47-63.

Kikuchi, R. K. P., Leão, Z. M. A. N., Testa, V., Dutra, L. X. C. \& Spanó, S. 2003. Rapid assessment of the Abrolhos Reefs, Eastern Brazil (Part 1: stony corals and algae). Atoll Res. Bull. 496:172-187.

Kohler, K. E. \& Gill, S. M. 2006. Coral Point Count with Excel extensions (CPCe): a Visual Basic program for the determination of coral and substrate coverage using random point count methodology. Comput. Geosci. 32:12591269.

Leão, Z. M. A. N. \& Dominguez, J. M. L. 2000. Tropical coast of Brazil. Mar. Pollut. Bull. 41:112-122.

Leão, Z. M. A. N. \& Kikuchi, R. K. P. 2001. The Abrolhos reefs of Brazil. In Seeliger, U. \& Kjerfve, B. (Eds.) Coastal Marine Ecosystems of Latin America. Ecological Studies (Analysis and Synthesis). Vol. 144. Springer-Verlag, Berlin, pp. 83-96.

Leão, Z. M. A. N. \& Kikuchi, R. K. P. 2005. A relic coral fauna threatened by global changes and human activities Eastern Brazil. Mar. Pollut. Bull. 51:599-611.

Leão, Z. M. A. N., Kikuchi, R. K. P. \& Testa, V. 2003. Corals and coral reefs of Brazil. In Cortês, J. (Ed.) Latin America Coral Reefs. Elsevier Publisher, Amsterdam, pp. 9-52.

Littler, D. S. \& Littler, M. M. 2000. Caribbean reef plants: an identification guide to the reef plants of the Caribbean, Bahamas, Florida and Gulfof Mexico. OffShore Graphics Inc., Washington, DC, 542 pp.

Maneveldt, G. W. 2005. A global revision of the nongeniculate coralline algal genera Porolithon Foslie (defunct) and Hydrolithon Foslie (Corallinales, Rhodophyta). Ph.D. dissertation, University of the Western Cape, Cape Town, $690 \mathrm{pp}$.

Maneveldt, G. W. \& Keats, D. W. 2014. Taxonomic review based on new data of the reef-building alga Porolithon onkodes (Corallinaceae, Corallinales, Rhodophyta) along with other taxa found to be conspecific. Phytotaxa 190:216-249.

Mariath, R., Riosmena-Rodríguez, R. \& Figueiredo, M. 2012. Lithothamnion steneckii sp. nov. and Pneophyllum conicum: new coralline red algae (Corallinales, Rhodophyta) for coral reefs of Brazil. Algae 4:249-258.

Mariath, R., Riosmena-Rodríguez, R. \& Figueiredo, M. A. O. 2013. Succession of crustose coralline red algae (Rhodophyta) on coralgal reefs exposed to physical disturbance in the southwest Atlantic. Helgol. Mar. Res. 67:687-696.

Matsuda, S. 1989. Succession and growth rates of encrusting crustose coralline algae (Rhodophyta, Cryptonemiales) in the upper fore-reef environment off Ishigaki Island, Ryukyu Islands. Coral Reefs 7:185-195.

Moura, R. L., Secchin, N. A., Amado-Filho, G. M., FranciniFilho, R. B., Freitas, M. O., Minte-Vera, C. V., Teixeira, J. B., Thompson, F. L., Dutra, G. F., Sumida, P.Y. G., Guth, A. Z., Lopes, R. M. \& Bastos, A. C. 2013. Spatial patterns of benthic megahabitats and conservation planning in the Abrolhos Bank. Cont. Shelf Res. 70:109-117.

Nelson, W. A. 2009. Calcified macroalgae: critical to coastal ecosystems and vulnerable to change: a review. Mar. Freshw. Res. 60:787-801.

Nunes, J. M. C., Guimarães, S. M. P. B., Donnangelo, A., Farias, J. \& Horta, P. A. 2008. Taxonomic aspects of three species of non-geniculate coralline algae from Bahia State, Brazil. Rodriguesia 59:75-86.

Penrose, D. 1992. Neogoniolithon fosliei (Corallinaceae, Rhodophyta), the type species of Neogoniolithon, in southern Australia. Phycologia 31:338-350.

Perry, C. T., Spencer, T. \& Kench, P. S. 2008. Carbonate budgets and reef production states: a geomorphic perspective on the ecological phase-shift concept. Coral Reefs 27:853-866.

Pueschel, C. M. \& Saunders, G. W. 2009. Ramicrusta textilis sp. nov. (Peyssonneliaceae, Rhodophyta), an anatomically complex Caribbean alga that overgrows corals. Phycologia 48:480-491.

Quinn, J. F. 1982. Competitive hierarchies in marine benthic communities. Oecologia 54:129-135.

Reis, V. M., Karez, C. S., Mariath, R., de Moraes, F. C., de Carvalho, R. T., Brasileiro, P. S., da Gama Bahia, R., de Cruz Lotufo, T. M., Ramalho, L. V., Moura, R. L., Francini-Filho, R. B., Pereira-Filho, G. H., Thompson, F. L., Bastos, A. C., Salgado, L. T. \& Amado-Filho, G. M. 2016. Carbonate production by benthic communities on shallow coralgal reefs of Abrolhos Bank, Brazil. PLoS ONE 11:e0154417.

Riosmena-Rodríguez, R., Woelkerling, W. J. \& Foster, M. S. 
1999. Taxonomic reassessment of rhodolith-forming species of Lithophyllum (Corallinales, Rhodophyta) in the Gulf of California, Mexico. Phycologia 38:401-417.

Rösler, A., Perfectti, F., Peña, V. \& Braga, J. C. 2016. Phylogenetic relationships of corallinaceae (Corallinales, Rhodophyta): taxonomic implications for reef-building corallines. J. Phycol. 52:412-431.

Segal, B. \& Castro, C. B. 2011. Coral community structure and sedimentation at different distances from the coast of the Abrolhos Bank, Brazil. Braz. J. Oceanogr. 59:119-129.

Silbiger, N. J., Guadayol, O., Thomas, F. I. M. \& Donahue, M. J. 2014. Reefs shift from net accretion to net erosion along a natural environmental gradient. Mar. Ecol. Prog. Ser. 515:33-44.

Sissini, M. N., Oliveira, M. C., Gabrielson, P.W., Robinson, N. M., Okolodkov, Y. B., Riosmena-Rodríguez, R. \& Horta, P. A. 2014. Mesophyllum erubescens (Corallinales, Rhodophyta): so many species in one epithet. Phytotaxa 190:299-319.

Steneck, R. S. 1985. Adaptations of crustose coralline algae to herbivory: patterns in space and time. In Toomy, D. F. \& Nitecki, M. H. (Eds.) Paleoalgology. Springer-Verlag, Berlin, pp. 352-366.

Steneck, R. S. 1986. The ecology of coralline algal crusts: convergent patterns and adaptive strategies. Annu. Rev. Ecol. Evol. Syst. 17:273-303.

Steneck, R. S. \& Adey, W. H. 1976. The role of environment in control of morphology in Lithophyllum congestum, a Caribbean algal ridge builder. Bot. Mar. 19:197-216.

Sweatman, H., Delean, S. \& Syms, C. 2011. Assessing loss of coral cover on Australia's Great Barrier Reef over two decades, with implications for longer-term trends. Coral Reefs 30:521-531.

Tâmega, F. T. S. \& Figueiredo, M. A. O. 2007. Distribution of crustose coralline algae (Corallinales, Rhodophyta) in the Abrolhos reefs, Bahia, Brazil. Rodriguésia 58:941947.

Tâmega, F. T. S., Riosmena-Rodríguez, R., Mariath, R. \& Figueiredo, M. A. O. 2014. Nongeniculate coralline red algae (Rhodophyta: Corallinales) in coral reefs from Northeastern Brazil and a description of Neogoniolithon atlanticum sp. nov. Phytotaxa 190:277-298.

Tâmega, F. T. S., Riosmena-Rodríguez, R., Spotorno-Oliveira, P., Mariath, R., Khader, S. \& Figueiredo, M. A. O. 2015. Taxonomy and distribution of non-geniculate coralline red algae (Corallinales, Rhodophyta) on rocky reefs from Ilha Grande Bay, Brazil. Phytotaxa 192:267-278.

Verheij, E. 1993. The genus Sporolithon (Sporolithaceae fam. nov., Corallinales, Rhodophyta) from the Spermonde Archipelago, Indonesia. Phycologia 32:184-196.

Villaça, R. C. \& Pitombo, F. B. 1997. Benthic communities of shallow-water reefs of Abrolhos, Brazil. Rev. Bras. Oceanogr. 45:35-43.

Villas-Boas, A. B., Figueiredo, M. A. O. \& Villaça, R. C. 2005. Colonization and growth of crustose coralline algae (Corallinales, Rhodophyta) on the Rocas Atoll. Braz. J. Oceanogr. 53:147-156.

Vroom, P. S., Page, K. N., Kenyon, J. C. \& Brainard, R. E. 2006. Algae-dominated reefs: numerous reports suggest that reefs must be dominated by coral to be healthy, but many thriving reefs depent more on algae. Am. Sci. 94:430-437.

Woelkerling, W. J. 1988. The coralline red algae: an analysis of the genera and subfamilies of nongeniculate Corallinaceae. Oxford University Press, London \& Oxford, 268 pp.

Woelkerling, W. J., Irvine, L. M. \& Harvey, A. S. 1993. Growthforms in non-geniculate coralline red algae (Corallinales, Rhodophyta). Aust. Syst. Bot. 6:277-293. 